\title{
Working
}

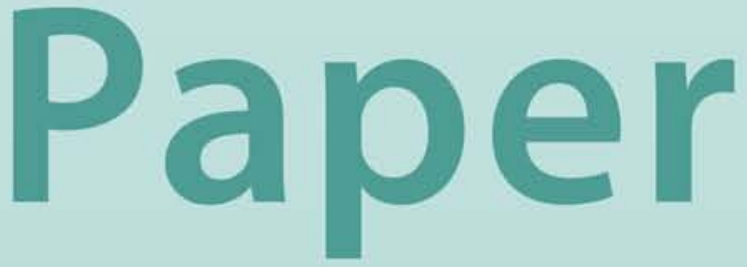




\section{Prudential Issues in Less Diversified Economies}

Aditya Narain, Pau Rabanal, and Steen Byskov 


\title{
IMF Working Paper
}

Monetary and Financial Systems Department

\section{Prudential Issues in Less Diversified Economies}

Prepared by Aditya Narain, Pau Rabanal, and Steen Byskov ${ }^{1}$

Authorized for distribution by David Marston

October 2003

\begin{abstract}
The views expressed in this Working Paper are those of the author(s) and do not necessarily represent those of the IMF or IMF policy. Working Papers describe research in progress by the author(s) and are published to elicit comments and to further debate.
\end{abstract}

This paper examines the prudential issues associated with credit concentration in less diversified economies (LDEs), which are identified as countries where one or two sectors represent a large share of exports. In preparing this analysis, the characteristics of their financial and banking systems and their interactions with the real sector are studied. The paper also examines the limitations on portfolio diversification confronting banks in these countries, both from the viewpoint of the real sector and of the financial system. The paper finds that banks in LDEs, particularly in low-income countries, appear to face higher risk than their peers in more diversified economies and makes suggestions for policy options and regulatory practices which could be encouraged in such systems.

JEL Classification Numbers: G21, G38

Keywords: Less Diversified Economies, Credit Concentration Risks, Capital Adequacy

Author’s E-Mail Address: anarain@imf.org, prabanal@imf.org, sbyskov@imf.org

\footnotetext{
I The authors are thankful to David Marston, Barbara Baldwin, Paul Kupiec, Thordur Olafsson, Jan-Willem van der Vossen, and seminar participants at the International Monetary Fund for helpful comments, and to Karen (K.C.) Craig for editorial assistance.
} 


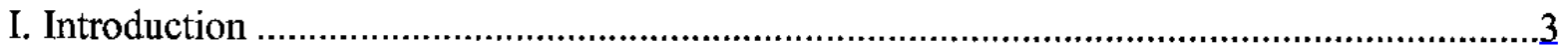

II. Prudential Regulation for Credit Exposures: International Practices.............................5

III. Less Diversified Economies and Certain Stylized Features ...........................................10

A. Export Concentration as a Proxy for Lack of Diversification ...............................10

B. Macroeconomic Features of Less Diversified Economies ................................12

C. Performance of the Banking Sector in Less Diversified Economies .....................16

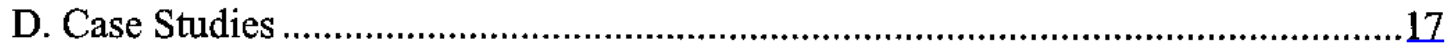

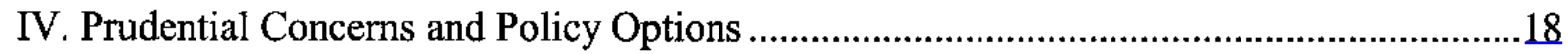

A. Financial Infrastructure and Market Development Issues .................................22

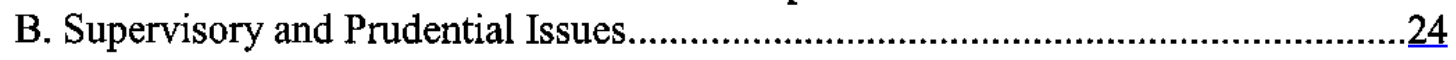

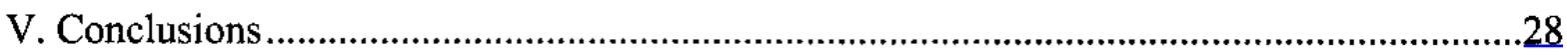

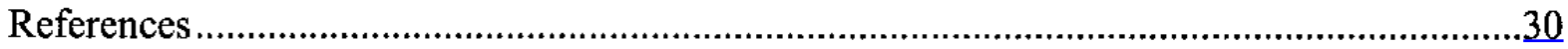

Tables

1. List of Export Concentration Countries........................................................................11

2. Selected Less Diversified Economies and Main Sectors .................................................12

3. Selected Correlations and Macroeconomic Indicators ...............................................13

4. Macro Indicators of Selected Countries..........................................................................15

5. Banking Performance Indicators...........................................................................16

6. Main Features of Selected Case Studies .....................................................................19 


\section{INTRODUCTION}

Banks in less diversified economies (LDEs) typically face a loan market where the highquality assets are concentrated in one industry or sector. ${ }^{2}$ In some cases, a large share of depositors may also be associated with the same sector. Hence, on the asset side, the bank's capital may be exposed to positively correlated credit risk, such that problems in the concentrated sector may lead a significant number of borrowers, whose cash flows are derived from operations in that sector, to fail to meet their repayment obligations. On the liability side, the problem arises from funding being dependent on a few depositors linked to the same industry/sector who may cause a liquidity constraint by suddenly withdrawing their deposits.

In the event of a terms of trade shock to a less diversified economy, the mechanism of bank balance sheet deterioration would work as follows: an adverse terms of trade shock hits the economy and profits of exporting firms decrease. On the banks assets side, an increase in nonperforming loans (NPLs) is likely to occur. Similarly, the decrease in households and the corporate sectors net worth induces a withdrawal of deposits of the banking system. As a result, the banking sector is left as vulnerable, if not more so, than the rest of the economy to terms of trade shocks, and business-cycle volatility becomes higher than if the country were able to diversify or hedge risks. ${ }^{3}$

Although credit concentration occurs in well-diversified economies as well as in LDEs, the problem in LDEs tends to be systemic. In a well-diversified economy, individual banks with large exposures to a single firm, a single sector, or a single region will be affected by the adverse economic performance of these entities. However, the banking system as a whole need not be affected: agents will be able to hedge domestically (at least partially through mechanisms such as transfers, unemployment insurance, and deposit insurance), and banks will be able to diversify their portfolios. The fundamental problem that LDEs confront is one of sectoral shocks becoming aggregate shocks with risks being correlated or associated. This situation makes it difficult to hedge or obtain insurance domestically.

Concentration risk arising out of exposure to particular industrial/economic sectors has been recognized to be a source of systemic risk. High exposures to a particular sector have been behind several bank failures in developed markets. A majority of the failures in U.S. banks in the 1980s have been attributed to a series of severe regional and sectoral recessions that hit banks in a number of banking markets (FDIC, 1997). Hence, bank supervisors normally

\footnotetext{
${ }^{2}$ The term sector is used in this paper to refer to both industrial and economic sectors. We distinguish between the prudential concerns with regard to concentration owing to correlated exposures in the same industry or sector and those concerns arising out of large exposures or exposures to related borrowers.

${ }^{3}$ See the study of the Chilean case by Caballero (2002).
} 
require banks to manage the credit risks arising from all types of concentrations in their loan portfolios through diversification. The focus of prudential regulation has, however, been the exposure of banks to large borrowers--either single borrowers or groups of related borrowers-for which explicit guidance is normally built into regulation.

Diversification is not always viewed as being able to reduce risk in banks. Some believe that specialization in lending (as to a particular industry or sector) can reduce risk, since specialized banks can better and more efficiently assess credit risk within their specialization. Thus, specialization can become a source of competitive advantage. A recent BIS (Bank for International Settlements - Basel) Working Paper ${ }^{4}$ on the effects of diversification versus specialization on the return to and risk of banks concludes that diversification of banks assets is "not guaranteed to produce superior performance and/or greater safety for banks" and cautions against regulation aimed at "encouraging bank level portfolio and/or activity diversification."

The use of export concentration to identify LDEs in this paper is based on evidence from other studies which show that the lack of diversification in exports makes the banking sector vulnerable through large fluctuations in the terms of trade. Other things being equal, countries with relatively low export diversification are more susceptible to banking crises. ${ }^{5}$ Small economies, which are usually less diversified than larger ones, typically face large fluctuations in their terms of trade.

Analyzing the effects of LDEs on the banking sector is made difficult by the scarcity of data, so the analysis is also built partly around data on individual country experience derived from various sources. In characterizing the set of LDEs, some common features emerge. Less diversified countries are typically small, both in economic terms and in the size of the financial sector. They are open to trade, which makes them vulnerable to terms of trade shocks, and relatively closed in terms of financial flows, reflecting the lack of investment opportunities inward and the lack of investment capacity outward. The banking industry tends to be highly concentrated, with a small number of banks accounting for a large share of loans and deposits. The financial system is likely to be less developed: typically banks dominate the financial system, and the role of non-bank financial institutions (NBFIs) such as pension funds or insurance companies, is small. Even when securities and capital markets are in place, they usually do not function smoothly, and they tend to be thin and shallow, with small transaction volumes. The high-income LDEs-New Zealand, Iceland and Chile, are exceptions to this pattern. When the banking performance of LDEs as a group is compared with that of peer groups with similar income levels, there is evidence of higher credit risk, (as

\footnotetext{
${ }^{4}$ Acharya, Hasan, and Saunders (2002).

${ }^{5}$ See Wilson and Caprio (2002), Caprio and Klingebiel (1996), or Kaminsky and Reinhart (1999).
} 
reflected in the higher NPL ratios); less private sector credit generation; and higher returns demanded by banks, especially in the low-income LDEs.

Concentration of entities in the industrial sector may itself further inhibit diversification. In a small economy with concentrated banking and industrial sectors, the banks and industrial firms may be related through common ownership or common customers. These characteristics of LDEs do not provide sufficient opportunities for the transfer of risk to mitigate concentration and accentuate the vulnerabilities that exist on account of sectoral concentration.

A wide variety of products and instruments have been developed to facilitate the mitigation and transfer of credit risk arising out of concentrations. On the one hand, a bank which originates a loan product can either continue to hold the risk after origination and mitigate it using collateral and/or guarantees. Or, on the other hand, it can transfer the risk, in full or in part, to other banks or institutions which have an appetite for credit risk and are either willing to buy the risk or to sell protection against the risk. The techniques of transferring credit risk to other market participants are collectively referred to as credit risk transfers (CRTs) and cover a range of instruments and products from contractual transfers like financial guarantees and credit insurance, risk-sharing techniques like loan syndication and consortium financing, secondary-market products like asset-backed securities, and derivative products like credit default swaps (CDS). They can also be categorized as funded (like syndications and traded loans) and nonfunded (like insurance and CDSs). The possibility of applying CRT techniques to LDEs is discussed in Section IV.

The rest of the paper is organized as follows: Section $\amalg$ describes the international practices regarding prudential limits on credit risk concentration, which tend to focus on large credit exposures, and reviews some cross-country evidence. Section III identifies a set of LDEs based on export concentration, and evaluates certain relevant characteristics in order to identify their stylized features. The performance of the banking sector in LDEs is analyzed and compared with a peer group (in terms of income levels) in order to determine whether sectoral concentration inhibits banking system performance. Section IV discusses the prudential issues that arise in LDEs based on the findings of Section III, and a number of possible supervisory approaches and policy options are recommended to national authorities. Section $\mathrm{V}$ concludes the study.

\section{Prudential Regulation for Credit Exposures: InTERnATIONAL Practices}

Bank Supervisors normally require banks to manage credit risks arising from all types of concentrations in the loan portfolio through diversification. The Basel Committee on Banking Supervision recognizes that "risk concentrations are arguably the single most 
important cause of problems in banks." ${ }^{16}$ Though risk concentration itself may arise in bank assets, liabilities, or off-balance sheet items, or even through the execution or processing of transactions, supervisors are mostly concerned with credit risk exposures. Credit risk is often the most material risk concentration in banks, and limiting the exposure of banks to large borrowers - either single or groups of related borrowers-is a theme reiterated by the Basel Committee in its guidelines on credit risk $(1991,2000)$.

These guidelines urge supervisors to consider measures to limit bank exposures to concentrated forms of credit risk in general and large exposures in particular. When the Basel Core Principles were formulated in 1997, Principle 9 (credit risk) also stressed the need for supervisors to set prudential limits to restrict bank exposure to single borrowers or groups of related borrowers, but did not explicitly cover concentration risk arising out of exposures to industrial/economic sectors.

Thus, Core Principle 9 states that "Banking supervisors must be satisfied that banks have management information systems, which enable management to identify concentrations within the portfolio, and supervisors must set prudential limits to restrict bank exposures to single borrowers or groups of related borrowers." An earlier best practices paper states that 25 percent of total bank capital is a desirable target for an upper limit on single credit exposures. A reporting threshold of 10 percent of total bank capital is also suggested. The European Commission, through its directive 2000/12, establishes the following limits: "A credit institution may not incur an exposure to a client or group of connected clients the value of which exceed 25 percent of its own funds." This limit is reduced to 20 percent if that client or group of connected clients is the parent undertaking or subsidiary of the credit institution. Finally, a credit institution may not incur large exposures which in total exceed 800 percent of its own funds.

These limits on large credit exposures are suggested for a private sector borrower or group of closely related borrowers' loans. They ignore the situation where a bank has a concentrated loan book: one which contains a relatively high proportion of sizeable single exposures, even if none of them is especially large. The risk of such a situation may be magnified if the majority of these borrowers are linked to a common economic activity or industry/sector, but explicit guidelines regarding sectoral concentration are not stated in the Basel Core Principles.

Even so, concentration risk arising out of exposure to particular industrial/economic sectors has been recognized to be a source of systemic risk. The Working Group set by the BIS in 1999 to draw lessons from the 1997-98 Asian financial crisis highlighted the need for effective internal controls on and monitoring of large exposures, particularly those

\footnotetext{
${ }^{6}$ BIS (April 2003).

${ }^{7}$ BIS (1991).
} 
counterparties outside formal limits and exposures representing geographical and sectoral concentrations.

High exposures to a particular sector have been behind bank failures in developed markets, too. A majority of the failures in U.S. banks in the 1980s have been attributed to a series of severe regional and sectoral recessions that hit banks in a number of banking markets (FDIC, 1997). Bank failures in this period were highly concentrated in relatively few regions, and the incidence of failure was particularly high in states characterized by economic downturns related to exposure to the oil sector, real estate-related downturns, and agricultural recessions, and were often compounded by prohibitions against branching that limited the banks ability to diversify geographically. In such situations, prudential limits on large exposures to single and related borrowers would not be enough to prevent a call on capital in the event of problems posed by unrelated but highly correlated borrowers linked to the same industry/sector.

Supervisors tend to specifically address concentration risks by placing prudential limits on the amount of a bank's capital that can be committed to a single borrower or a group of related borrowers. A scrutiny of the Banking Supervision Regulatory Database (BSRD) ${ }^{8}$ sample of regulations of 56 agencies covering 62 countries shows that all but two supervisors imposed regulatory limits based on some measure of capital on large exposures to a single or related group of borrowers. ${ }^{9}$ All these countries either prohibit exceeding these mandated limits, or require prior approval of or consultation with the supervisory authority in case these limits are exceeded. Of the two exceptions, while New Zealand requires banks only to disclose all exposures greater than 10 percent of capital, Australia leaves the imposition and review of limits to the bank boards and requires banks to consult the supervisors only in the event the exposure to another bank exceeds 30 percent of capital. The remaining countries mandate limits varying from 15 percent (Bahrain, the United States, Ethiopia, and Georgia) to 75 percent of capital (West African Economic and Monetary Union). ${ }^{10}$ This is measured variously as net owned funds, own funds, paid-up capital and reserves, core capital, capital base, total capital, net capital or regulatory capital. Brazil expresses these limits in terms of net adjusted assets. Large (or significant) exposures are expressed as 5 percent to 25 percent of capital and most countries placed a limit of aggregate of all large exposures to be less than 800 percent of the capital of the institution. Most countries also carried over the same limits to apply to related party/group exposures and commonality of ownership, financial interest and repayment source were the common criteria for establishing the relationship. Separate

${ }^{8}$ The BSRD is a database maintained by the Monetary and Financial Systems Department at the $\mathrm{IMF}$, covering banking legislative and regulatory instruments of IMF member countries.

${ }^{9}$ For additional details, see Morris (2001).

${ }^{10}$ Peru and the United Arab Emirates prescribed lower limits of 5 percent and 6 percent, respectively, for certain classes of counterparties. 
limits for groups are in place in India (15 percent of capital funds for single borrower and 40 percent for groups of related borrowers); Jamaica ( 20 percent, 40 percent). In addition to placing prudential limits, the regulations in some countries also impose a sublimit, requiring that all exposures above a certain percentage, but below the regulatory maximum, necessarily be approved by a Board resolution.

However, concentration risks arising out of industrial or sectoral exposures are not normally subjected to similar prudential regulation, that is, where unrelated borrowers may be linked by virtue of repayment potential to the same economic activity. In contrast, many countries specifically make mention in their regulations of the sectors which are fully or partially exempt from the single and group borrower norms, notable being claims on specified governments and central banks (Mexico, Egypt, Czech Republic, Slovak Republic, and the European Union), banks (Ghana, La Commission Bancaire de l'Afrique Centrale (COBAC)), exports (Pakistan, Malawi), low-income housing (Mexico), infrastructure projects (India). On the other hand, the one subsector which often attracts specific exposure limits in regulation across countries is real estate, probably because asset price bubbles involving real estate have been identified with bank failures. For instance, failed banks in the United States in the 1980's episode tended to have a much higher ratio of commercial real estate loans to total assets and the real estate sector (FDIC, 1997). Thus, several countries have established limits on real estate-Kenya has a limit of 25 percent of deposit liabilities, the Philippines 20 percent, the United Arab Emirates 20 percent, while Switzerland empowers the Banking Commission to impose limits on exposure to undeveloped land. The IMF, too, includes residential and commercial real estate loans (separately) to total loans in their encouraged set of Financial Stability Indicators (FSIs), underscoring the importance that supervisors give to concentration in this sector.

Several supervisors recognize the importance of sectoral concentration in their practices. However, generally no explicit prudential limits are set, and the emphasis and approach varies across jurisdictions. Canada, Bulgaria, Latvia, and India require banks to fix internal limits to industrial and geographic sectors. Egypt, Malta, Slovenia, and the Slovak Republic require banks to behave prudently with regard to industrial or economic sectors and like Bahrain, review sectoral risk concentration. In addition, Mexico and Panama retain the legal right to establish limits to prevent concentration of risks in a market segment/major economic sector. Malawi requires statutory and external auditors to highlight loans granted to the major economic sectors. Ghana actually places an advisory limit on sectoral concentration and considers exposure to any single economic sector exceeding 15 to 20 percent of total credit as not prudent. Peru, on the other hand, prohibits the central bank from imposing any sectoral restrictions, though at the same time it also prohibits the incorporation of any institution to serve only one economic sector. However, even if no prudential limits are prescribed, a majority of supervisors tend to collect data on some measure of sectoral concentration of loans to total loans. A recent IMF Working Paper reports that 60 percent of a sample of 100 national authorities collected such data. ${ }^{11}$

${ }^{11}$ See Slack (2003). 
The potential vulnerability arising out of excessive asset concentration in a particular sector(s) has also been recognized by the IMF in its work on FSIs. The study found that one set of indicators, which national authorities would be encouraged to compile and disseminate, is the "sectoral distribution of loans to total loans." The Draft Compilation Guide on the FSIs comments that "a large concentration of aggregate credit in a specific resident economic sector or activity may signal an important vulnerability of the deposit-taking sector to the level of activity, prices and profitability in that sector or activity." 12 The resident sectors are defined as deposit-takers, central banks, various governments, other financial corporations, non-financial corporations, households, nonprofit institutions serving households, and nonresidents. The other financial corporations are broken up into insurance and pension funds, security dealers, investment funds, other financial intermediaries, and financial auxiliaries. The Guide goes further to suggest that classifying loans by type of borrower using the International Standard Industrial Classification (ISIC) of all Economic Activities and/or by type of loan, such as consumer, commercial and industrial might be a particularly relevant approach when an economy has specific systemically important industries, such as petroleum and agriculture.

However, these classifications of sectors, sub-sectors, and economic activity could also fail to capture the aggregate risk arising out of the exposure to a commodity-the procurement, production, and processing of which could span several categories. In the case of an economy where the majority of the households earn their livelihoods from activity linked to one commodity, industry or sector, then even a category like "lending to households" can contribute to the concentration risks in the system, since the ability of households to repay their loans would be dependent on their income stream from the economic activity related to these. Thus, over and above the suggested categories, supervisors may have to use their own classifications for capturing exposure related to a sector, keeping materiality and relevance in mind.

Another way of looking at sectoral concentration is by focusing on those specific industries or commodities around which a major part of economic activity might focus in a country. The commodity might be such that banks finance the entire cycle from production or extraction to the export of the finished product, in the course of which different economic activity descriptions might be straddled. An issue of concern might then be the case of those economies where a large proportion of bank loans might be tied to economic activity built around a specific commodity, industry or sector, downturns in the fortunes of which might feedback to the banks significantly. In the next section, an attempt is made to identify such less diversified economies and to bring out certain stylized features.

${ }^{12}$ See IMF (2003). 


\section{Less Diversified Economies and Certain STylized Features}

The issue of sectoral concentration may be magnified in the case of LDEs. Risks arising from banks choosing a sectorally undiversified loan portfolio exist in all economies, but when all banks have similar undiversified portfolios, it creates a systemic risk rather than a risk to an individual bank. In a LDE, the return on most assets may be highly correlated to the fortunes of the predominant sector, directly or indirectly. Further, if the population of both borrowers and depositors are dependent on returns from the dominant sector, the bank may be squeezed from both sides in the event of a downturn of the sector, with a run on deposits exacerbating the insolvency of the borrowers. This apprehension has in the past led to calls for setting higher prudential standards for banks facing higher risks in countries with less diversified production sectors.

The following sections first discuss export concentration as a measure of diversification and describe how the LDE sample was selected. Then, the relationships are examined between overall GDP, exports in the main sector, and nonperforming loans, a main indicator of banking performance. Finally, a comparison of banking performance indicators in LDEs and a comparable peer (by income level) is performed.

\section{A. Export Concentration as a Proxy for Lack of Diversification}

There are two main reasons to focus on exports concentration as a proxy for real sector concentration: first, other things being equal, countries with relatively low export diversification are more susceptible to banking crises. The lack of diversification in the exports of such economies makes their banking sector vulnerable through large fluctuations in the terms of trade. When bank customers find that the terms of trade have turned sharply against them, their ability to service existing loans is likely to be impaired. Wilson and Caprio (2002) find that an index of exports concentration positively and significantly affects the likelihood and costs of a banking crisis. In analyzing 29 episodes of banking crises, Caprio and Klingebiel (1996) find that volatile terms of trade in highly concentrated economies preceded banking crises. In particular, they report that 75 percent of the developing countries in their sample that experienced banking crises suffered a terms of trade decline of at least 10 percent prior to the crisis. Kaminsky and Reinhart (1999) likewise identify terms of trade deterioration as one of the stylized facts preceding banking crisis in small industrial countries and emerging countries. Volatility in the terms of trade is particularly pronounced for countries with high export concentrations (e.g., Venezuela, Ecuador); small economies, usually less diversified than larger ones, typically face large fluctuations in their terms of trade.

Another reason for focusing on exports in measuring concentration is that the classification has certain advantages over the ISIC classification system, which is commonly used both for national accounts and sectoral loan classification. With this classification, it is difficult to trace the many stages of the production process of the main commodity. It might well be that many tertiary sector activities (trade, transportation, services) are still linked to the production of the main commodity, and detection through sectoral GDP figures is not 
straightforward. Also, the category of "households" in sectoral loan concentration usually obtains values between 25 percent and 40 percent, but it is difficult to know how many of these households are dependent on the fortunes of the evolution of the country's main export.

The sample is selected by the following criteria (see also Table 1). First, one sector must represents 50 percent of total exports, or two sectors must represent 80 percent of exports, except for the case of manufacturing. This restriction is imposed because the focus is on commodity exporting countries, though we acknowledge that this may lead to overlooking LDEs where a service industry (e.g., tourism, banking, or advertising.) contributes to a large share of GDP. Second, oil exporting countries are eliminated from our sample, since this industry tends to be self-financed. Third, countries with population of less than 250.000 are excluded as they may be constrained in the scope and size of their financial infrastructure. Fourth, the sample is restricted to about twenty countries for which reasonably consistent data exists. In particular, we focus on countries for which at least four years of observations of NPLs exist.

Table 1. List of Export Concentration Countries

\begin{tabular}{|l|l|l|}
\hline & \multicolumn{1}{|c|}{ Population more than 250,000 } & \multicolumn{1}{c|}{ Population less than 250,000 } \\
\hline Oil & Algeria, Azerbaijan, Angola, Bahrain, Brunei, & \\
& Cameroon, Ecuador, Gabon, & \\
& Iran, Iraq, Kazakhstan, Kuwait, Libya, & \\
& Nigeria, Norway, Oman, & \\
& Qatar, Russia, Saudi Arabia, Sudan, & \\
& Syrian Arab Republic, Trinidad and Tobago, \\
& Turkmenistan, United Arab Emirates, Venezuela, \\
& Yemen. & \\
\hline Non-Oil & $\begin{array}{l}\text { Benin, Bhutan, Botswana, Burundi, } \\
\text { Cape Verde, Central African Republic, } \\
\text { Chile, Côte d'Ivoire, Ethiopia, Fiji, Ghana, } \\
\text { Guatemala, Guinea, Guinea-Bissau, } \\
\text { Honduras, Iceland, Jamaica, Kenya, } \\
\text { Maldives, Mali, Mauritania, Mongolia, } \\
\text { Mozambique, Niger, Nicaragua, New } \\
\text { Zealand, Panama, Papua New Guinea, Paraguay, } \\
\text { Tanzania, Togo, Uganda, } \\
\text { Zambia, Zimbabwe. }\end{array}$ & \\
\hline
\end{tabular}

Source: Fund staff estimates based on the UN COMTRADE database.

Based on these considerations, attention is restricted to the following countries, the dominant sectors mentioned in accompanying brackets: 
Table 2. Selected Less Diversified Economies and Main Sectors

\begin{tabular}{ll|ll}
\hline \multicolumn{1}{c}{ Country } & Concentrated Sector(s) & \multicolumn{1}{c}{ Country } & \multicolumn{1}{c}{ Concentrated Sector(s) } \\
\hline Belize & (agriculture) & Iceland & (fish catch and fish processing) \\
Benin & (agriculture) & Jamaica & (mining) \\
Botswana & (mining) & Mauritania & (mining; fish catch) \\
Chile & (mining) & Mali & (mining; cotton) \\
Côte d'Ivoire & (agriculture for exports) & Mongolia & (mining) \\
Ethiopia & (agriculture) & New Zealand & (agricultural products) \\
Fiji & (agriculture for exports) & Paraguay & (agriculture) \\
Ghana & (mining; cocoa) & Senegal & (fishing; phosphates) \\
Guatemala & (agricultural products) & Togo & (mining; cotton) \\
Kenya & (agriculture) & Uganda & (coffee; sugar) \\
Honduras & (agriculture) & Zambia & (copper) \\
\hline
\end{tabular}

Source: Fund staff estimates based on UN COMTRADE database.

Note: When there are two concentrated sectors, the first and second are separated by semicolon.

\section{B. Macroeconomic Features of Less Diversified Economies}

Acknowledging the imperfection of this methodology of identifying LDEs and the dominant sectors, in Table 3 correlations are presented for 22 LDEs and 30 dominant sectors between (i) GDP growth and NPLs, (ii) GDP growth of the main sector and NPLs, (iii) GDP growth of the main sector and GDP growth of the rest of the economy, and (iv) NPLs and the behavior of the terms of trade. These correlations are produced with the longest possible series available for each country, using annual data. This last exercise attempts to measure to what extent there is scope for domestic diversification by looking at the co-movement between the country's main sector and the rest of the economy.

In theory, a strong negative correlation between GDP growth and NPLs would be expected: if the economy grows below trend, then the ratio of NPLs to total loans should increase. This found to hold for nine countries in the sample (41 percent) - Jamaica, Kenya, Botswana, Paraguay, New Zealand, Zimbabwe, Togo, Iceland, and Mauritania all exhibit strong or very strong negative correlations between the two variables. Next, another group of countries (27 percent)-Chile, Fiji, Mongolia, Mali, Ethiopia and Benin — basically show no correlation between these two variables (correlations ranging between -0.11 and 0.11 ). For the remaining seven countries (32 percent) - Guatemala, Senegal, Côte d'Ivoire, Uganda, Honduras, Ghana and Belize - there is a somewhat unexpected positive correlation between overall GDP growth and NPLs. When taking a look at the correlation between the main sector GDP growth and NPLs, the results change markedly. In 11 cases (36 percent), the correlation is negative or highly negative, in 13 cases ( 43 percent) the correlation is basically zero, and only in 6 cases ( 20 percent) the correlation is positive or highly positive. 
Table 3. Selected Correlations and Macroeconomic Indicators $1 /$

\begin{tabular}{|c|c|c|c|c|c|c|c|}
\hline Country & $\begin{array}{l}\text { NPL, } \\
\text { GDP } \\
\text { Growth }\end{array}$ & $\begin{array}{l}\text { NPL, } \\
\text { Main } \\
\text { Sector } \\
\text { Growth }\end{array}$ & $\begin{array}{l}\text { Growth } \\
\text { Main } \\
\text { Sector, } \\
\text { Rest }\end{array}$ & $\begin{array}{l}\text { NPL, } \\
\text { Terms } \\
\text { of trade }\end{array}$ & $\begin{array}{c}\text { GDP } \\
\text { (Billions } \\
\text { of US\$) }\end{array}$ & $\begin{array}{c}\text { Trade } \\
\text { Openness } \\
\text { (in percent) }\end{array}$ & $\begin{array}{c}\text { Capital } \\
\text { Account } \\
\text { Openness } \\
\text { (in percent) }\end{array}$ \\
\hline Jamaica & -0.91 & -0.30 & 0.34 & 0.90 & 7.70 & 97 & 11.5 \\
\hline Kenya & -0.89 & -0.71 & 0.81 & -0.97 & 11.30 & 45 & 10.5 \\
\hline Botswana & -0.87 & -0.75 & -0.19 & -0.43 & 4.10 & 99 & 8.0 \\
\hline Paraguay & -0.65 & 0.01 & 0.19 & 0.68 & 6.80 & 78 & 4.1 \\
\hline \multicolumn{8}{|l|}{ New } \\
\hline Zealand & -0.55 & -0.29 & 0.74 & 0.02 & 49.83 & 52 & 14.0 \\
\hline Zimbabwe & -0.47 & 0.10 & 0.48 & -0.31 & 7.10 & 67 & 4.5 \\
\hline \multirow[t]{2}{*}{ Togo $2 /$} & -0.42 & -0.26 & 0.17 & -0.49 & 1.25 & 72 & 10.2 \\
\hline & & -0.09 & -0.08 & & & & \\
\hline Iceland & -0.36 & -0.41 & 0.03 & -0.86 & 7.20 & 55 & 16.5 \\
\hline \multirow[t]{2}{*}{ Mauritania $2 /$} & -0.35 & -0.46 & 0.00 & 0.54 & 1.05 & 70 & 0.4 \\
\hline & & -0.27 & -0.47 & & & & \\
\hline Chile & -0.11 & -0.21 & -0.26 & -0.27 & 66.82 & 85 & 15.5 \\
\hline Fiji & -0.05 & 0.02 & 0.54 & -0.40 & 1.80 & 65 & 7.2 \\
\hline Mongolia & 0.01 & 0.18 & -0.26 & -0.06 & 1.02 & 77 & 13.2 \\
\hline \multirow[t]{2}{*}{ Mali 2/ } & 0.05 & 0.03 & -0.20 & -0.26 & 2.37 & 62 & 5.3 \\
\hline & & 0.12 & 0.20 & & & & \\
\hline Ethiopia & 0.11 & 0.12 & 0.19 & -0.78 & 6.23 & 42 & 4.3 \\
\hline Benin & 0.11 & -0.15 & 0.69 & -0.65 & 2.27 & 37 & 6.7 \\
\hline Guatemala & 0.33 & -0.88 & -0.53 & -0.50 & 20.90 & 38 & 5.8 \\
\hline \multirow[t]{2}{*}{ Senegal $2 /$} & 0.35 & -0.18 & -0.98 & 0.68 & 4.87 & 49 & 4.7 \\
\hline & & -0.52 & -0.88 & & & & \\
\hline Côte d'Ivoire & 0.41 & -0.04 & -0.33 & 0.21 & 9.20 & 71 & 8.1 \\
\hline \multirow[t]{2}{*}{ Uganda $2 /$} & 0.42 & 0.55 & 0.40 & 0.69 & 6.34 & 26 & 3.3 \\
\hline & & 0.43 & 0.97 & & & & \\
\hline Honduras & 0.44 & 0.60 & 0.45 & -0.92 & 6.40 & 66 & 6.7 \\
\hline \multirow[t]{2}{*}{ Ghana 2/ } & 0.65 & 0.43 & 0.81 & 0.45 & 6.88 & 55 & 8.6 \\
\hline & & 0.43 & 0.51 & & & & \\
\hline Belize & 0.67 & 0.55 & -0.52 & -0.27 & 0.77 & 82 & 9.2 \\
\hline
\end{tabular}

Sources: IMF International Financial Statistic; Bankscope; Country Reports; and Fund staff estimates. $1 /$ The first four columns were constructed with the longest possible series. The fifth column uses the latest available observation. The last two columns use a 10-year average with the latest available observations.

2/ Data for these countries reflects the two main sectors.

Evidence is strong when we look at the correlation coefficient between the main sector's GDP growth and the rest of the economy GDP growth. The idea of this exercise is to see how the rest of the economy moves in tandem with the country's main export, and try to obtain an indicator of the potential for domestic diversification. Positive correlations, close to one, would indicate strong correlation with the rest of the economy, and few diversification opportunities. This is the only case in eight countries - Ghana (both sectors), Honduras, 
Uganda (both sectors), Kenya, New Zealand, Benin, Fiji and Zimbabwe. In the remaining 14 countries in our sample, however, correlations are close to zero or negative. The most striking case is Senegal, for which the two sectors are correlated in a highly negatively way with the rest of the economy, with correlations of -0.88 and -0.98 .

In the fourth column of Table 3, the sample correlations between NPLs and the terms of trade are presented. A negative correlation between these two variables would be expected: an increase in the price of exports or a decline in the price of imports should increase profits in the corporate sector, and this would be reflected in a decline in nonperforming loans. We find evidence that favors this hypothesis, since 13 cases in our sample exhibit strong negative correlations. Only 3 cases exhibit a correlation close to zero, while 6 cases exhibit an unexpected positive correlation. It should be noted that, some of the cases that include a positive correlation (Mauritania, Senegal, Uganda, and Ghana) are economies for which two sectors dominate exports, and for which the terms of trade could have compounded effects.

The results overall suggest that NPLs are more strongly negatively correlated with the main sector's performance than with overall GDP growth, suggesting that NPLs, and therefore credit risk, may be more linked to the main sector than to the rest of the economy. Similarly, when the focus is on the correlation between the terms of trade and NPLs, a negative correlation is found in a majority of cases. At the same time, the movement in tandem between the main sector and the rest the economy growth rate is strongly positively related only in one-third of the sample, thus presenting possibilities of domestic diversification opportunities for banks.

The other main features of the group of LDEs can be seen in the remaining columns of Table 3. For purposes of comparison, Table 4 presents similar data for a sample of representative group of diversified economies, both developed and developing. The LDEs are relatively small economies, with GDP less than US\$10 billion in most cases. The only countries with larger GDP are New Zealand, Chile, Kenya, Ecuador, and Guatemala. Even these numbers are much lower than those for developing countries such as Mexico (US $\$ 600$ billion) or Brazil (US $\$ 400$ billion), and further away from industrialized countries like Japan or the United States

Next, two common measures of openness are evaluated. These variables are constructed using averages of the last 10 years of available observations. First, there is a measure of trade openness using the indicator of imports and exports as a percentage of GDP. Here the degree of openness to trade varies between countries, ranging from 26 percent for Uganda to 99 percent of Botswana. However, most countries are very open to trade, with index values between 60 percent and 100 percent, much larger than the set of selected "diversified" countries. This feature of high openness and concentration makes the LDEs highly vulnerable to terms of trade shocks, and could explain a negative correlation between terms of trade and NPLs. 
Then, a measure of financial openness is constructed. In the literature on economic performance and growth, two sets of measures are used. ${ }^{13}$ One looks at the presence of controls on payments with respect to capital account transactions as reported in the IMF's Annual Report on Exchange Arrangements and Exchange restrictions. The main disadvantage of such binary indicators is that they measure only presence and not the intensity of such controls. Hence, a variable that tries to capture the volume of financial transactions is used: the ratio of inward and outward foreign direct investment, portfolio investment and other investment items in the financial account of the balance of payments as a share of GDP. It is found that most countries are relatively closed in that variable showing the volume of financial transactions, with the lowest values being Uganda ( 3.3 percent) and Paraguay (4.1 percent). Only the middle-to-high income countries (New Zealand, Iceland, Chile), which have more developed financial systems, have ratios higher than 10 percent. Other countries that have ratios higher than 10 percent are known to have received large amounts of FDI. There is also large heterogeneity in the control group, but the values tend to be larger on average.

Table 4. Macro Indicators of Selected Countries

\begin{tabular}{|c|c|c|c|}
\hline Country & $\begin{array}{c}\text { GDP } \\
\text { (Billions of US\$) }\end{array}$ & $\begin{array}{c}\text { Trade } \\
\text { Openness } \\
\text { (in percent) }\end{array}$ & $\begin{array}{c}\text { Capital } \\
\text { Account } \\
\text { Openness } \\
\text { (in percent) }\end{array}$ \\
\hline United States & 10,588 & 23.0 & 11.0 \\
\hline Japan & 4,100 & 20.0 & 5.4 \\
\hline United Kingdom & 1,430 & 50.0 & 46.0 \\
\hline Korea, Rep. of & 427 & 57.5 & 8.5 \\
\hline Germany & 2,140 & 45.0 & 19.0 \\
\hline Spain & 588 & 46.0 & 22.3 \\
\hline Mexico & 623 & 47.0 & 7.5 \\
\hline Brazil & 411 & 22.6 & 10.0 \\
\hline
\end{tabular}

Source: IMF International Financial Statistics.

Note: Trade openness consists of measures as import and export as a share of GDP, whereas Capital Account Openness is measured as gross inward and outward FDI, portfolio investments and other investments items in the financial account of the balance of payments as a share of GDP.

Having reviewed the macroeconomic environment in LDEs, the next subsection focuses on the conduct and performance of banks in LDEs.

${ }^{13}$ See, for instance Kose et al. (2003). 


\section{Performance of the Banking Sector in Less Diversified Economies}

In LDEs, banks are faced with the inherent risk of loan concentration. To compensate for this risk, banks should require a higher return and a competitive equilibrium would generate less lending, other things equal. Banks are analyzed with respect to credit generation to the private sector, efficiency, profitability and asset quality in Table 5. Banks in LDEs do indeed generate less credit, but this only holds true for low and lower-middle income LDEs. ${ }^{14}$ The more advanced high income LDEs may have alternative ways of mitigating the risks and may be less constrained by the lack of diversification. ${ }^{15}$

Table 5. Banking Performance Indicators 1/ (in percent)

\begin{tabular}{|c|c|c|c|c|c|c|c|c|c|c|}
\hline & \multicolumn{2}{|c|}{$\begin{array}{l}\text { Private Sector } \\
\text { Credit/GDP 2/ }\end{array}$} & \multicolumn{2}{|c|}{$\begin{array}{c}\text { Net Interest } \\
\text { Margin 3/ }\end{array}$} & \multicolumn{2}{|c|}{$\begin{array}{c}\text { Return on } \\
\text { Equity } 3 /\end{array}$} & \multicolumn{2}{|c|}{$\begin{array}{r}\text { Return on } \\
\text { Assets 3/ }\end{array}$} & \multicolumn{2}{|c|}{$\begin{array}{c}\text { Non- } \\
\text { Performing } \\
\text { Loans 4/ }\end{array}$} \\
\hline & All & LDEs & All & LDEs & All & LDEs & All & LDEs & All & LDEs \\
\hline $\begin{array}{l}\text { Low- and lower- } \\
\text { middle incomc } \\
\text { Upper-middle }\end{array}$ & 21.1 & 18.7 & 5.3 & 7.6 & 22.4 & 21.3 & 1.6 & 1.8 & n.a. & 13.6 \\
\hline and high-income & 48.7 & 58.2 & 3.0 & 3.1 & 13.5 & 19.3 & 1.2 & 1.9 & n.a. & 2.2 \\
\hline Total & 30.0 & 22.3 & 4.4 & 6.8 & 18.7 & 20.9 & 1.5 & 1.8 & n.a. & 11.7 \\
\hline
\end{tabular}

Sources: Bankscope; IMF International Financial Statistics; Country Reports; and FSSA reports.

$1 /$ The indicators are averaged across countries by assigning equal weight to each country. The indicators for each country are weighted averages across banks in the country. The income classification is done according to the World Bank's World Development Report income classification.

2/ Private sector credit reflects average from 1991-2002.

3/ Net interest margin, ROE and ROA reflect averages from 1995-2001.

4/ NPLs reflect averages of four most recent observations. NPLs were not available for many countries, so the totals are not reported.

Since banks in LDEs are constrained in diversifying their portfolios, they should require higher marginal revenue on their loans and only select the best lending opportunities. This leads to a prediction that banking systems in LDEs would command higher margins. Notwithstanding the difficulties in collecting this information on a robust comparative basis, the analysis underscores the fact that diversification of the economy does play a role in determining the performance of banking systems. LDEs have higher net interest margins than

\footnotetext{
${ }^{14}$ Differences in the two groups could also reflect the fact that many countries in our sample suffered banking crises during the period, and hence display lower banking performance indicators than historical averages. For instance Jamaica, Ecuador, and Paraguay.

${ }^{15}$ Only a few countries among the UDEs fall in the upper-middle or high income group, and conclusions on high and upper-middle income UDEs are therefore not very strong.
} 
other economies, and again the effect is particularly strong in low and lower-middle income LDEs.

On one hand, ROA and ROE are expected to be higher in LDEs reflecting higher returns compensating for higher risks. On the other hand, borrowers in concentrated economies are likely to be large or associated with one major group, since they predominantly represent just one sector. Therefore, borrowers might be able to exert some market power in the credit market, so banks will not be able to charge a premium for lending to the concentrated sector. It turns out that ROE and ROA are indeed higher in LDEs, but particularly so in high or upper-middle income countries. Thus, the banks in high or upper-middle income LDEs are better able to translate higher margins into higher profits than banks in low or lower middle income LDEs.

NPLs tend to be higher in LDEs, and within the group of LDEs, tend to be higher for the low-income countries. ${ }^{16}$ For this indicator, it has not been possible to collect data for most countries, so a group of control countries is used for comparison. It is found that the figures for the control group are much smaller: United States (average of last seven years, 1.05 percent), the United Kingdom (2.9 percent), Spain ( 2.3 percent), Germany ( 2.5 percent), Korea (5.6 percent), Japan (6.1 percent), Brazil (7.8 percent), and Mexico (10 percent).

Thus, it emerges from this analysis that banks, especially in low income LDEs, are faced with a higher degree of risk than their more diversified peers and seek higher margins as a compensation for the higher risk, and this higher credit risk is evidenced in the form of higher NPLs. Further, as most of these economies are very open to international trade, and as previous studies have shown that undiversified exports, trade openness, and terms of trade shocks are among the factors that precede banking crises, we conclude that credit risk arising from sectoral concentration is an issue of prudential concern in the LDEs. One reason this relationship does not hold consistently in higher income LDEs may be that the latter offer greater financial diversification opportunities through their more developed financial systems, a theme which will be revisited in the next section when we discuss the stylized features of LDEs.

\section{Case Studies}

This subsection presents certain features of selected countries from the sample of LDEs. Significant characteristics of the banking sector, such as development and size of the banking and financial systems, market shallowness, and the regulatory framework regarding large exposures, are examined. From this analysis, it is found that countries with lack of

${ }^{16}$ It is well known that countries differ widely in their methodology of identifying and classifying NPLs and that these differences could be further heightened by differences in related regulatory or accounting prescriptions. Conclusions are made acknowledging this caveat. 
diversification in the real sector have mixed experiences with loan concentration in the banking sector. Each country has been examined in more depth using available sources, such as: country reports, FSSA reports, and the World Bank Financial Regulation Database. ${ }^{17}$

This subsection presents patterns which emerge from data on these countries' banking and financial systems. As may be seen from Table 6 the financial sector tends to be dominated by the banking system with non-bank financial institutions, pension funds, and insurance companies playing a marginal role in these countries. Second, the size of credit to the private sector over GDP is also small, denoting the fact that there are few opportunities to invest locally. The higher income LDEs, Iceland and Chile, are the exceptions to this pattern. Third, concentration in the banking industry appears as a small number of banks, and a small number of banks accounting for a large share of loans and deposits-reflecting the lack of financial and banking system development. Fourth, even though countries have regulation in place to limit large credit exposures (with the exception of Guatemala), these limits are relatively high for Senegal and Gabon, which belong to WAEMU and CEMAC, respectively. Only one country in the sample (Ghana) explicitly incorporates sectoral limits in legislation. Finally, two countries (Ghana and Gabon) have a minimum capital adequacy ratio lower than the Basel prescribed 8 percent.

The case of Chile and Botswana deserves some mention: even though they are less diversified economies, they do not have a loan concentration problem in their banking systems. This issue can be explained through the scale of initial investment to start extraction activities: since mining is a capital-intensive industry, just like the case of oil, it might well be that the domestic banking system does not have the capital to start this economic activity. As a result, financing is obtained from abroad, either through foreign lending or through multinationals supplying the initial capital, and, hence, the domestic banking system does not have a large exposure to the country's main sector. Of course, as long as the price of the main export affects the business cycle, it will have an impact on banking performance (in Table 3, we could see that, for Botswana, that was indeed the case).

\section{Prudential Concerns and Policy Options}

As previously indicated, less diversified economies and in particular the low-income countries among them are typically small, relatively less integrated financially, and they face a higher degree of concentration in the banking sector, which inhibits competition and interferes with diversification opportunities. The structure of the markets in these less diversified economies may also inhibit the opportunities to diversify credit risk arising from

${ }^{17}$ See Barth, Caprio, and Levine (2001). 
Table 6. Main Features of Selected Case Studies

\begin{tabular}{|c|c|c|c|c|c|}
\hline COUNTRY & BOTSWANA & ICELAND & GHANA & CHILE & ZAMBIA \\
\hline NPL & 3.2 & 3.5 & 16.3 & 1.5 & 25.3 \\
\hline $\mathbf{R O A}$ & 5.0 & 0.8 & 3.5 & 0.7 & 4.4 \\
\hline ROE & 30.3 & 9.8 & 39.7 & 13.3 & 34.7 \\
\hline MINIMUM CAR & 15 percent & 8 percent & 6 percent & 8 percent & $\begin{array}{c}5 \text { percent Tier } 1 \text {, } \\
10 \text { percent Total Capital }\end{array}$ \\
\hline $\begin{array}{l}\text { Banking System Assets/ } \\
\text { Financial System Assets }\end{array}$ & 78 percent & 43 percent & 80 percent & 46 percent & 70 percent \\
\hline Credit Private Sector /GDP & 20 percent & 100 percent & 14 percent & 70 percent & 8 percent \\
\hline Main Exports & $\begin{array}{l}\text { Pearls and other precious } \\
\text { stones ( } 84 \text { percent) }\end{array}$ & $\begin{array}{l}\text { Fish catch and fish } \\
\text { processing ( } 50 \text { percent) }\end{array}$ & $\begin{array}{l}\text { Gold ( } 40 \text { percent), } \\
\text { Cocoa ( } 40 \text { percent) }\end{array}$ & $\begin{array}{l}\text { Copper ( } 40 \text { percent) } \\
\text { Agricultural Products } \\
\text { (20 percent) }\end{array}$ & Copper (66 percent) \\
\hline Credit Concentration Comments & $\begin{array}{l}\text { Mining only takes } 4 \text { percent } \\
\text { of total loans. }\end{array}$ & $\begin{array}{l}\text { Fisheries and fish processing } \\
\text { receive } 25 \text { percent of total } \\
\text { loans. Banks have several } \\
\text { large borrowers in common. }\end{array}$ & $\begin{array}{l}\text { Exposure to one single } \\
\text { company represents } \\
109 \text { percent of total bank } \\
\text { capital. }\end{array}$ & $\begin{array}{l}\text { Credit concentration does not } \\
\text { seem to be an issue, } \\
\text { especially in the copper } \\
\text { sector. }\end{array}$ & $\begin{array}{l}20 \text { largest borrowers hold } \\
56 \text { percent of total loans, and } \\
40 \text { largest borrowers, } \\
91 \text { percent. At a sectoral } \\
\text { level the distribution seems } \\
\text { fairly diversified. }\end{array}$ \\
\hline Banking Concentration & $\begin{array}{l}\text { HIGH. Four banks operate in } \\
\text { Botswana. }\end{array}$ & $\begin{array}{l}\text { HIGH. Three commercial } \\
\text { banks hold } 75 \text { percent of } \\
\text { total loans and deposits of } \\
\text { the banking system. }\end{array}$ & $\begin{array}{l}\text { HIGH. Three largest banks } \\
\text { represent } 89 \text { percent of total } \\
\text { loans, and five largest banks } \\
\text { hold } 78 \text { percent of total } \\
\text { deposits of the banking } \\
\text { system }\end{array}$ & $\begin{array}{l}\text { MEDIUM. Three largest } \\
\text { banks hold } 49 \text { percent of } \\
\text { total assets of the banking } \\
\text { system. Ten largest banks } \\
\text { hold } 85 \text { percent of total } \\
\text { assets and deposits. }\end{array}$ & $\begin{array}{l}\text { HIGH. Three largest banks } \\
\text { hold } 84 \text { percent of banking } \\
\text { system assets. } 83 \text { percent of } \\
\text { total deposits are held by the } \\
5 \text { largest institutions. }\end{array}$ \\
\hline $\begin{array}{l}\text { Legislation / Regulation on } \\
\text { Credit Exposures / } \\
\text { Concentration }\end{array}$ & $\begin{array}{l}\text { Lending in excess of } \\
10 \text { percent of unimpaired } \\
\text { capital to one borrower } \\
\text { requires prior approval of } \\
\text { board of directors. Lending } \\
\text { in excess of } 30 \text { percent of } \\
\text { unimpaired capital to one } \\
\text { borrower requires prior } \\
\text { written approval of Central } \\
\text { Bank. }\end{array}$ & $\begin{array}{l}\text { The legislation on large } \\
\text { credit exposures follows the } \\
\text { European Commission } \\
\text { directive } 2000 / 12 \text {. This } \\
\text { directive defines large single } \\
\text { exposure as } 25 \text { percent of } \\
\text { bank capital, and suggests } \\
\text { that the sum of large } \\
\text { exposures should not exceed } \\
800 \text { percent of total bank } \\
\text { capital. }\end{array}$ & $\begin{array}{l}\text { Secured advances in excess } \\
\text { of } 25 \text { percent of net worth or } \\
\text { unsecured advances in } \\
\text { excess of } 10 \text { percent of net } \\
\text { worth are prohibited. } \\
\text { Sectoral credit exposure: any } \\
\text { single economic sector } \\
\text { exceeding } 15 \text { to } 20 \text { percent } \\
\text { of total credit might not be } \\
\text { considered as prudential. }\end{array}$ & $\begin{array}{l}5 \text { percent of bank capital if } \\
\text { the loan is given to an } \\
\text { individual or firm, } 10 \text { percent } \\
\text { of bank capital if the credit is } \\
\text { denominated in foreign } \\
\text { currency and used for export } \\
\text { purposes, } 15 \text { percent of bank } \\
\text { capital if the credit finances } \\
\text { public work activities, and } \\
25 \text { percent of bank capital if } \\
\text { the credit is fully secured } \\
\text { with collateral. Loans } \\
\text { exceeding these limits are } \\
\text { strictly prohibited. }\end{array}$ & $\begin{array}{l}\text { A single large exposure is } \\
\text { defined as } 25 \text { percent of } \\
\text { capital, and the limit to total } \\
\text { large exposures is } \\
600 \text { percent of regulatory } \\
\text { capital. }\end{array}$ \\
\hline Type of Markets & $\begin{array}{l}\text { Securities (Primary and } \\
\text { Secondary), Interbank, Stock } \\
\text { Exchange }\end{array}$ & $\begin{array}{l}\text { Securities (Primary and } \\
\text { Secondary), Interbank, Stock } \\
\text { Exchange }\end{array}$ & $\begin{array}{l}\text { Securities (Primary and } \\
\text { Secondary), Interbank, Stock } \\
\text { Exchange }\end{array}$ & $\begin{array}{l}\text { Securities (Primary and } \\
\text { Secondary), Interbank, Stock } \\
\text { Exchange }\end{array}$ & $\begin{array}{l}\text { Securities (Primary and } \\
\text { Secondary), Interbank, Stock } \\
\text { Exchange }\end{array}$ \\
\hline $\begin{array}{l}\text { Stock Market Capitalization } \\
\text { /GDP }\end{array}$ & 16 percent & 70 percent & 23 percent & 64 percent & 7 percent \\
\hline $\begin{array}{l}\text { Does There Exist Deposit } \\
\text { Insurance? }\end{array}$ & No & Yes & No & Yes & No \\
\hline
\end{tabular}


Table 6. Main Features of Selected Case Studies (Concluded)

\begin{tabular}{|c|c|c|c|c|}
\hline COUNTRY & UGANDA & SENEGAL & GABON & GUATEMALA \\
\hline NPL & 14.6 & 6.7 & 7.6 & 11.1 \\
\hline ROA & 2.1 & 1.7 & 2.2 & 1.0 \\
\hline ROE & 32.8 & 22.4 & 33.2 & 12.0 \\
\hline MINIMUM CAR & 8 percent & 8 percent & 5 percent $1 /$ & 9 percent \\
\hline $\begin{array}{l}\text { Banking System Assets/ } \\
\text { Financial System Assets }\end{array}$ & 82 percent & 85 percent & 90 percent & 87 percent \\
\hline Credit Private Sector /GDP & 6 percent & 17 percent & 10 percent & 18 percent \\
\hline Main Exports & $\begin{array}{l}\text { Agricultural Products } \\
\text { (60 percent) of which coffee } \\
\text { is } 20 \text { percent }\end{array}$ & $\begin{array}{l}\text { Groundnuts ( } 10 \text { percent }), \\
\text { Phosphate }(15 \text { percent }), \\
\text { Fishing ( } 25 \text { percent })\end{array}$ & $\begin{array}{l}\text { Oil ( } 60 \text { percent), Wood } \\
\text { (15 percent) }\end{array}$ & $\begin{array}{l}\text { Agricultural Products } \\
\text { (50 percent) }\end{array}$ \\
\hline $\begin{array}{l}\text { Credit Concentration } \\
\text { Comments }\end{array}$ & $\begin{array}{l}\text { Top five borrowers represent } \\
40 \text { percent of total loans and } \\
\text { top twenty borrowers, } \\
64 \text { percent. Large credit } \\
\text { exposures represent } \\
145 \text { percent of total bank } \\
\text { capital. }\end{array}$ & $\begin{array}{l}\text { State Owned Groundinut } \\
\text { Company has credits } \\
\text { outstanding for } 70 \text { percent of } \\
\text { Banking System Capital. } \\
\text { Five largest borrowers } \\
\text { represent } 177 \text { of total capital } \\
\text { of the banking system. }\end{array}$ & $\begin{array}{l}\text { The percentage of loans to } \\
\text { forestry to total loans is } \\
12 \text { percent. The oil industry } \\
\text { does not have important } \\
\text { linkages to the financial } \\
\text { sector. }\end{array}$ & $\begin{array}{l}\text { Banks' exposures to single } \\
\text { borrowers or groups of } \\
\text { related borrowers are } \\
\text { currently unknown. }\end{array}$ \\
\hline Banking Concentration & $\begin{array}{l}\text { HIGH. Four foreign owned } \\
\text { banks account for } 73 \text { percent } \\
\text { of total sector assets, } \\
68 \text { percent of sector loans } \\
\text { and } 75 \text { percent of deposits. }\end{array}$ & $\begin{array}{l}\text { MEDIUM. Four largest } \\
\text { banks represent } 70 \text { percent of } \\
\text { total loans and deposits of the } \\
\text { banking system }\end{array}$ & $\begin{array}{l}\text { HIGH. Largest bank } \\
\text { accounts for } 40 \text { percent of } \\
\text { total deposits and loans, three } \\
\text { largest banks account for } \\
80 \text { percent of total deposits } \\
\text { and loans. }\end{array}$ & $\begin{array}{l}\text { LOW. The banking system } \\
\text { is not particularly } \\
\text { concentrated: the five largest } \\
\text { banks hold } 38 \text { percent of } \\
\text { deposits, and the seven } \\
\text { largest banks account for } \\
\text { more than } 50 \text { percent of total } \\
\text { loans. }\end{array}$ \\
\hline $\begin{array}{l}\text { Legislation / Regulation on } \\
\text { Credit Exposures / } \\
\text { Concentration }\end{array}$ & $\begin{array}{l}\text { Limits for credit } \\
\text { concentration are set to } \\
25 \text { percent of bank capital for } \\
\text { single exposures, and for } \\
\text { connected lending. }\end{array}$ & $\begin{array}{l}800 \text { percent of capital for the } \\
\text { total of large exposures } \\
\text { (loans larger than } 25 \text { percent } \\
\text { of capital). For single large } \\
\text { exposures, the limit is } \\
75 \text { percent. }\end{array}$ & $\begin{array}{l}\text { Connected lending is limited } \\
\text { to } 15 \text { percent of capital. For } \\
\text { large exposures, the limit is } \\
45 \text { percent of capital for an } \\
\text { individual client, and } \\
800 \text { percent of capital for the } \\
\text { total of large exposures } \\
\text { (loans larger than } 25 \text { percent } \\
\text { of capital) }\end{array}$ & $\begin{array}{l}\text { The prudential regulations } \\
\text { and requirements do not } \\
\text { allow the Superintendence of } \\
\text { Banks to guarantee that } \\
\text { supervised banks do not lend } \\
\text { excessively to single or } \\
\text { related borrowers. }\end{array}$ \\
\hline Type of Markets & $\begin{array}{l}\text { Securities (Primary and } \\
\text { Secondary), Interbank, Stock } \\
\text { Exchange }\end{array}$ & $\begin{array}{l}\text { Securities (Primary), } \\
\text { Interbank, Stock Exchange }\end{array}$ & $\begin{array}{l}\text { Securities (Primary), } \\
\text { Interbank }\end{array}$ & $\begin{array}{l}\text { Securities (Primary), } \\
\text { Interbank, Stock Exchange }\end{array}$ \\
\hline $\begin{array}{l}\text { Stock Market } \\
\text { Capitalization /GDP }\end{array}$ & 2.5 percent & NA & NA & 1.1 percent \\
\hline $\begin{array}{l}\text { Does there exist deposit } \\
\text { insurance? }\end{array}$ & Yes & No & No & Yes \\
\hline
\end{tabular}

Sources: Bankscope; Country Reports; FSSA Reports; World Bank Financial Regulation Database,;and Fund staff estimates. 
sectoral concentrations. In such economies, the banking sector comprises a relatively high proportion of the financial sector and other financial institutions may not be available to assume or share the credit risk. Capital markets and bond markets tend to be less developed, and rating agencies and a ratings culture may not be present, all of which would be prerequisites for evolution of development of markets for CRT techniques and the instruments through which such risks could be transferred.

A wide variety of products and instruments have been developed to facilitate the mitigation and transfer of credit risk arising out of concentrations ranging from funded financial products (like syndications and traded loans) to non-funded ones (like insurance and credit default swaps). Bank guarantees and letters of credit are the more common instruments, but have limited risk-transfer value in the LDE scenario, since the risk remains within the concentrated banking system - that is, unless the risk-taking institution is a foreign bank/branch or domestic other financial institution. However, to the extent that these instruments redistribute risk within the banking system, they would work toward modulating excess sectoral concentration in a single institution. The same can be said for loan syndication/ participation, in which the originating bank passes on a part of the risk (and the return) at the time of origination to other participating banks.

Products like securitizations and credit derivatives have a limited presence even in major developing countries, and are currently outside the scope of most of the countries in the sample of less diversified economies. A recent report (BIS, 2003) which has evaluated the spread and depth of the credit risk transfer (CRT) markets has also examined the development of CRTs in three of the larger emerging economies (Brazil, Korea and Mexico) and identified the following impediments in the development of the securitization and credit derivatives markets involving such problems as: (i) legal constraints such as the absence of an appropriate framework for creditor rights and corporate insolvency; (ii) difficulty in pricing in the absence of a deep bond market and hence that of a long-term yield curve (iii) lack of an established institutional investor base; and (iv) lack of clear regulation. Thus, the findings of the report suggest that well-developed domestic financial markets and institutions are a pre-condition for the success of CRTs in developing countries.

The BIS report, however, is not pessimistic about the future. Although it identifies the original driver of the growth in the markets to have been the desire to reduce regulatory capital, the current forces behind market growth are seen to be the desire to diversify the credit risk portfolio and also diversify the income sources to include more fee based income. Growth in these CRT markets has also been driven by the demand for credit risk outside the banking system and their use as a funding device in the face of increased intermediation which reduces access to cheap retail deposits.

The report points out that, for example, in Mexico, a credit derivative market has existed between local and foreign institutions since 1995 and that a market for CDS exists for the sovereign risks of all the three countries in New York and London. Another factor which could fuel the demand for emerging market in credit default swaps is that credit rating agencies tend to assign higher credit risk ratings to diversified portfolios, and the fact that 
most international players in the CRT business are large international players and hence able to facilitate cross-border transactions.

The possible approaches and policy options available to supervisors in the less diversified economies can be categorized into two areas: (i) financial infrastructure and market development issues (to facilitate risk diversification and transfer); and (ii) supervisory and prudential issues (to address risk concentrations). While the former are longer term and likely to require political mandate, the latter are more within the realm of supervisors. Of course, if reducing vulnerability (and hence increasing financial stability) by increasing risk diversification is on the policy agenda, then both these issues would have to be addressed.

\section{A. Financial Infrastructure and Market Development Issues}

Although not within the scope of this paper, two broad approaches could be taken to facilitate sectoral risk diversification in the longer term. Briefly, the first is to diversify the dependence on the sector itself ${ }^{18}$ through development of alternative income sources for the economy as a whole. In a sense, this has been a policy priority for many of the 'commodity' economies which have sought to diversify across sectors or industries over the past few decades.

The second approach is to expand the institutional and geographical scope and size of the financial sector so as to permit the risk of the concentrated sector to be spread across a larger number of participants, both within and outside the domestic banking system. As pointed out by the BIS report (BIS, 2003), "diversification benefits will arise even if credit risk is simply redistributed within the system. Spreading it outside would further enhance the effect, and if spread across countries, may reduce banks vulnerability to domestic business cycles." This can by achieved in the following ways by:

(i) by addressing bank concentration and competition issues. As observed from our sample, most LDEs tend to have a very high concentration in the banking sector which in turn serves to concentrate the sectoral risk within a few institutions. Since data suggests that there may be diversification possibilities in other sectors, an increase in the number of banks may serve to redistribute risk and lower the possibility of failure of individual institutions.

(ii) by diversifying the portfolio of domestic banks and permitting/encouraging domestic banks to lend and borrow abroad. This policy approach would also be

\footnotetext{
${ }^{18}$ Iceland, for example, has made significant progress in diversifying its exports owing to conscious policy choices followed since the early 1990's, as a consequence of which the share of marine exports has fallen from 58 percent to 40 percent of total exports of goods and services in the period 1991-2001 (in which output increased by 37 percent), with aluminum/ ferrosilicon and travel and transportation increasing their share significantly in the same period. (IMF Country Report No. 02/130, July 2002).
} 
subject to several caveats. Banks in the LDEs may not have the skills or the presence to lend in foreign markets and would be largely diversifying by investing in foreign securities, which in turn bring on added foreign exchange risk. Borrowing overseas would be in the context of importing bank capital in the event that the domestic economy is capital constrained, but could come with higher costs.

(iii) by permitting greater participation of foreign institutions in domestic lending both directly and through local presence. Of course, there has to be a balance between importing volatile bank loans and more stable FDI, and some countries may strive to achieve this balance by providing incentives for FDI or by mandating certain amount of FDI in the industry sector.

(iv) In the case of small economies with inadequate infrastructure and resources in the same geographical region, mechanisms to facilitate regional financial integration through shared institutions and markets could be considered, as this could serve the purpose of expanding the size and scope of the financial sector, provide opportunities for cross border financial flow and ownership and provide diversification opportunities by removing the constraint of sectoral limitation. Many of the LDEs are in geographically contiguous regions and some $^{19}$ are already members of such regional arrangements which cover common central banks, supervisory infrastructure, and stock exchanges, though there is little data available to determine whether such arrangements have worked to provide diversification opportunities.

(v) by broadening the involvement of non-bank sector in lending and risk sharing. Though NBFIs raise their own regulatory framework issues, other institutions like insurance companies and pension funds have an appetite for credit risk which in turn would require developing the market for securitization and other CRT products to facilitate risk sharing both locally and cross-border of both banks and nonbanks.

${ }^{19}$ The West African Economic and Monetary Union (WAEMU) currently comprises Benin, Burkina Faso, Guinea Bissau, Côte d'Ivoire, Mali, Niger, Senegal, and Togo and the common central bank, (BCEAO) is responsible for the supervision of the banking sector and the control and distribution of credit. The dominant industries in these countries are linked variously to agriculture, fishing and mining, and hence should offer opportunities for sectoral diversification across borders. 


\section{B. Supervisory and Prudential Issues}

As has been mentioned earlier, supervisors normally deal with concentration issues by imposing limits on the amount of capital that can be committed to one type of exposure or those exposures which are strongly correlated, such as those of related groups of borrowers. The relationship is normally one based on common control, ownership or management. It can also extend to entities that have a common source of income or other commercial links which cannot be undone in the short term. The commonality does not cover a common sector or industry though very often, supervisory oversight may be focused on certain key sectors which have a history of volatility independent of the jurisdiction such as exposure to real estate or capital markets. Exposures to these sectors may in turn be subject to supervisory limits and monitoring.

While supervisors may require banks to monitor exposure to a particular economic/industrial sector, specific limits are not normally prescribed in regulation because of scope and coverage issues - for example, in the following situations: (i) determining just what types of activities and firms would be covered; (ii) deciding what ancillary activities would be part of the sector, (iii) establishing what would be the extent of involvement in a particular sector which would trigger this limit; (iv) In certain cases institutions may have been set up to specialize in financing to a particular sector as a public policy measure or may have over time acquired specialization in financing a particular sector. In both cases, the asset portfolio would be dominated by exposure to the sector; (v) In the case of exposure to an industry or activity linked to a particular commodity or produce, the related activities may span several conventional industries or sectors and the correlation may not be captured by the individual limits; and (vi) Further, the individual borrowers may themselves hedge their income streams in other ways, for example through a partial diversification of their own activities, and could thus warrant differential sectoral limits.

Moreover, mandating sector limits across the banking system could be counterproductive especially in the typical LDE unless alternative sources of funding to industry or sufficient avenues and instruments to mitigate and transfer risk were available to banks, as set forth in the preceding paragraphs. However, the practice followed by several supervisors to subject sectors with histories of volatility such as commercial real estate is a sound practice and should not be dispensed with on the above grounds.

In such a situation, supervisors should require banks to identify and manage the risks arising out of concentration to sectors. With greater insight into the sectoral linkages and business of the borrower, banks are better placed to ascertain whether they exposed materially to particular sectors, and to actively manage the related risks. Supervisors in turn need to see that such limits are appropriate and are not generally inconsistent with the other credit concentration limits, since in times of distress of the sector, the portfolio of borrowers linked to that sector could behave akin to a group of related borrowers. 
Banks should therefore be encouraged to take the following courses of action:

(i) Bank boards establish a well-documented policy on exposure to each dominant sector, industry or commodity.

(ii) Banks collect and report data on these concentrations on at least the same frequency as other concentrations, both to their boards and the supervisors.

While the limits themselves may depend upon circumstances particular to the economy (i.e., the extent to which the economy lacks diversification and mitigation opportunities) or the individual banks themselves, a useful guidepost could be that the limits not be markedly different from the limit prescribed by the supervisors for groups of related borrowers.

It may also be prudent for the board to prescribe sub-limits beyond which additional exposure to the sector should require approval of the board or at a minimum that the Board be informed. The policy could also require the use of enhanced credit risk mitigation (collaterals, guarantees etc.) once the sub-limits are exhausted and also favor the use of collateral, which in turn is less correlated to the sector in question.

This will require the banks to collect exposure data on the sector dimension in addition to the other concentrations that may already be collected and to that extent could require reorientation of the data collection and related internal systems of the bank.

Supervisors on their part should have the legal ability to require banks to set such limits, obtain information on these and to require banks to disclose their concentration to these sectors and statutory auditors to highlight concentration to major sectors. However, supervisors should clearly prescribe to which sectors, sub-sectors, industries or commodities would the reporting and other related regulations apply. A differential regime could also be considered where the dominant sector exposure is reported more frequently than the rest.

Supervisors should also have the authority to establish limits on individual banks or to the system as a whole on exposure to particular sectors, as such measures may be useful in times of distress, as well as to take corrective action in case this advice is not observed. Similarly, they should have the authority to prescribe the use of credit risk mitigating techniques, such as higher collateral requirements and guarantees for lending above bank or supervisor approved limits.

At the same time, supervisors in LDEs should ensure that other best practice concentration risk measures are built into regulation and observed by banks. This would include the limit on single borrowers and groups of related borrowers as forbearance in this regard could aggravate sectoral concentration risks in periods of distress. This would be especially true in cases where most large borrowers are linked to the dominant sector. As brought out earlier, most countries in the sample have regulations in place to limit such large exposures to within 25 percent of their capital, with the exception of Guatemala where no prudential limits have been prescribed and the WAEMU countries where relatively higher limits are in place. 
Supervisors should also have rules to limit connected lending and the authority to prohibit it if required. Given the small economy and concentration in the banking sector which is characteristic of the LDEs, there may potentially be cross ownership between the industry and banks. This in turn could provide banks greater incentive to attempt high risk 'ever greening' bail outs or asset quality cover ups in times of distress in the sector.

Further, in this scenario of interconnectedness, the large depositors (or the majority of depositors) could also be linked to the dominant sector. In the event of distress in the sector, depositors may withdraw their bank deposits to meet their liquidity needs and thus put pressure on the liquidity of the banking system. Banks should therefore periodically assess the extent of such deposits and build this sectoral element into their stress test analysis. Supervisors, in turn, should monitor large deposit concentrations (either above a threshold amount or number) by requiring banks to provide sector details for such large deposits in their off-site returns.

As suggested in Part $\mathrm{I}$, national authorities could consider compiling and disseminating data on "sectoral distribution of loans to total loans" as this will enable the other market participants to monitor this and hence strengthen market discipline. On their part, supervisors could use the reported data to determine both the individual and aggregate capital committed and at risk through stress tests. One of the many criticisms leveled against the current capital standards (1998 Basel Accord) is that the risk weighting framework does not take in to account the risks arising out of concentration nor does it provide any incentive for loan portfolio diversification. The revised proposals in the New Capital Accord (Basel II) also do not address the issue of concentration risks ${ }^{20}$ under Pillar I, which lays out the minimum capital requirements.

Under the 'standardized' approach, the risk weights are linked to the ratings given by external agencies, and there is no adjustment for concentration risk. Ratings agencies could design their ratings to take into account the concentration and positive correlations in the rated entity's credit portfolio. However, since most LDEs are unlikely to have significant ratings penetration or presence this may not immediately feed into the capital allocation process through risk-weighting. Supervisors can however keep this aspect in mind as they assess the ratings methodology of the qualifying ratings agencies.

The framework for the Internal Ratings-Based Approach (IRB) too does not take into account directly the risks of concentration to a sector. The initial proposals did, however, attempt to address one aspect of concentration through a methodology to take into account

${ }^{20}$ At the same time, the fact that the benefits of diversification are not explicitly recognized in the New Accord has also led to criticism that it does not provide appropriate incentives for banks in developed countries to invest in developing country paper [see Griffith-Jones, Stephany, Segoviano, Miguel and Spratt, Stephen (2002], which could also impede development of cross-border risk-transfer markets for LDEs. 
the "lumpiness" of the bank portfolios through a granularity adjustment ${ }^{21}$ to capital at risk. This would lead to an easing of capital required as the borrower concentration decreases and number of different borrowers grows. The granularity adjustment has not met with widespread approval and does not feature under Pillar I in the subsequent consultation paper (CP3). In any case, this adjustment would not take into account the situation of our stylized LDE banks, where the concentration may not be to borrowers per se but to borrowers in a particular sector. However, it provides a first step for the banks' own modeling of sector concentration risk. Banks which have the wherewithal (both the data and the skill/methodology) could introduce multifactor models that take into account the sectoral distribution of their credit portfolio in their capital calculations.

For the majority of banks and banking systems, any adjustment of capital requirements for concentration risk in a sector will have then to be addressed through Pillar II of the New Capital Accord ${ }^{22}$ which enjoins upon supervisors to adjust minimum capital requirements based upon the risk-profile of banks. As these requirements begin to apply, supervisors will be expected to move to a system of specifying risk-based capital for individual institutions. In such a system, it will be even more necessary for supervisors in LDEs to be able to assess the risk on account of sector concentration among other concentration risks.

Thus, in the event supervisors find that a bank has a relatively high risk profile arising from its exposure to a particular sector, then capital requirements should be increased from the minimum 8 percent of risk-weighted assets as or as prescribed in that jurisdiction. ${ }^{23}$ In the

${ }^{21}$ In the third consultative paper (CP3) of the Basel Capital Accord (2003), the granularity criterion has been retained for qualifying inclusion in the retail portfolio. The paper requires supervisors to be "satisfied" that the regulatory retail portfolio is sufficiently diversified to a degree that reduces the risks in the portfolio warranting the 75 percent risk weight. Moreover, it suggests setting a numerical limit that no aggregate exposure to one counterpart can exceed 0.2 percent of the overall regulatory retail portfolio.

${ }^{22}$ CP 3 has in fact placed the issue of credit concentration in Pillar 2 and suggested that banks should have a documented framework for addressing credit concentration of all types and that supervisors should take action in case banks do not address concentration risks adequately.

${ }^{23}$ In the first instance, supervisors should ensure that regulations in less diversified economies prescribe at least the minimum capital requirements of 8 percent of risk-weighted assets(for instance Ghana and Gabon have CARs of 6 percent and 5 percent, respectively). They should also have mechanisms to ensure that these prescriptions are in fact, met (for instance, in the WAEMU region, as of 2001, 21 out of 63 banks did not meet the minimum capital ratio of 8 percent and 50 banks exceeded the single borrower limit of 75 percent - see IMF Country Report No. 03/70, March 2003). Furthermore, in Ghana, the debt of one company to two large banks exceeded the total banking sector's capital (see 2001 Country Report). 
case of the typical LDEs, where the entire banking system may have a high level of sector concentration, supervisors may even consider raising the minimum capital adequacy requirement for the system as whole.(In fact, some supervisors in LDEs already require banks to have CAR higher than 8 percent in view of the higher risks which they consider their banking system to be subject to). Of course, supervisors would need to have objective methods of assessing the risk profile of institutions and categorizing them under different risk categories. This also requires supervisors to have the legal mandate to make this distinction and impose differential prudential norms and the ability to take corrective action if the requirements are not met.

Supervisors might employ different methods to assess the risk arising out of such concentration and translate them into capital requirements. In the simple CAMELS methodology, sectoral concentration risk could be specifically incorporated in the appropriate individual rating grades (for example in the $\mathrm{C}$, for capital) and the capital adequacy requirement scaled up based on the component rating. In the case of a bank using IRB, the approach may be directly adjusted to take into account the state of diversification in different sectors, although this would require the development of appropriate multi-factor models with asset correlations based on individual economy experience. Again, banks and their supervisors will have to keep this in mind as banks move toward internal models for capital allocation. As banks build data series for compiling default statistics integral to IRB approaches, data on exposure to sectors may have to be constructed in parallel, which would take into account the concentration in the different sectors.

Whether the approach followed is one of prescribing prudential limits or setting higher capital requirements, the key ingredient is risk awareness of sector concentration, and this is what supervisors in LDEs must instill in their banks.

\section{Conclusions}

Banks in LDEs may be confronted with somewhat higher risk of default on account of their high exposure to a dominant commodity or industry to which a major part of their borrowers (and hence their repayments) may be linked. This risk may also be accentuated by a bank's inability to reduce risks by diversifying across other domestic sectors. It may be further increased if the banking sector itself is concentrated or if it is not sufficiently open to a wider participation by foreign banks or exposure to foreign customers. Many of the economies identified as LDEs also have less developed financial markets and infrastructures which inhibit the development of credit-risk-transfer techniques and instruments. Bank concentration coupled with a high degree of bank intermediation also inhibits risk distribution. Although there is mixed evidence on the effect of the lack of sectoral diversification on bank performance across all LDEs, a higher level of credit risk is reflected in the higher NPLs and higher net interest margins in low-income LDEs. Very likely, the more developed financial markets in high-income LDEs provide more avenues to diversify the risk or mitigate it in other manners. 
Country experience shows that although some supervisors require banks to take such risks into account while lending, they do not themselves prescribe any prudential norms.

Supervisors may be hesitant to impose limits on lending to the dominant sector because of a host of issues, including the lack of other sources of domestic finance or of opportunities to transfer or hedge the risk. International best practices for industry/sectoral concentration have not yet been developed. Although the Basel Committee recognizes the significance of this risk and advises banks and supervisors to assess and monitor it, the capital standards do not build credit concentration risk into the capital methodology. In these circumstances, banks would do well to put in place systems to identify and review their exposures to the dominant sectors of their countries' economies and to set internal limits for exposure and requiring reporting to supervisors and for enhancing credit-risk-mitigation requirements beyond such limits.

Supervisors should review these limits to see whether they are appropriate across banks, should have the legal powers to impose prudential limits if required and to verify these exposures, either directly or through external auditors; and should require banks to disclose their exposure to the given sectors. The less stringent prudential requirements in some of the LDEs are a matter of concern, and supervisors should develop programs to introduce existing international standards and best practices in these jurisdictions. Supervisors should also have the ability to prescribe higher capital requirements for banks with higher risk profiles (taking into account sectoral concentration), as is envisaged in Pillar II of the New Basel Accord, and should develop appropriate methodologies for assessing this, which can be based either in existing CAMELS-based systems or developed as part of the proposed internal ratings-based approach. In addition, national authorities should promote appropriate financial infrastructure and market development, which would provide opportunities for banks to diversify these risks and enable them to participate in credit-risk-transfer arrangements across institutions and across borders. 


\section{References}

Acharya, V., I. Hasan, and A. Saunders, 2002, "Should Banks be Diversified? Evidence from Individual Bank Loan Portfolios," Bank for International Settlements Working Paper No. 118 (Basel).

Bank for International Settlements, 2003a, "Consultative Document on the New Capital Accord," April, (Basel).

_ _ 2003b, "Credit Risk Transfer," January (Basel).

$\ldots$ _. 1991, "Measuring and Controlling Large Credit Exposures,” January (Basel).

Barth, J., G. Caprio Jr., and R. Levine, 2001, "Regulation and Supervision of Banks Around the World: A New Database,” Policy Research Working Paper 2588 (Washington: World Bank).

Caballero, R., 2002, "Coping with Chile's External Vulnerability: A Financial Problem," (unpublished; Cambridge, Mass.: Massachusetts Institute of Technology).

Caprio, G., and D. Klingebiel, 1996, "Bank Insolvencies: Cross-Country Experience," Policy Research Working Paper No. 1620 (Washington: World Bank).

Federal Deposit Insurance Corporation, 1997 "History of the Eighties-Lessons for the Future," Volume I-An Examination of the Banking Crises of the 1980s and Early 1990s (Washington).

Griffith-Jones, Stephany, S. Sprat, and M. Segoviano., 2003, "Basel II and Developing Countries: Diversification and Portfolio Effects," December, (Sussex, United Kingdom: University of Sussex, Institute of Developmental Studies. Available via Internet: http://www.ids.ac.uk/ids/global/finance/ifpubs.html

International Monetary Fund, 2003, "Draft Compilation Guide of Financial Soundness Indicators," (Washington).

Kaminsky, G., and C. Reinhart, 1999, "Twin Crises: Causes of Banking and Balance-ofPayments Problems," American Economic Review, Vol. 89, No.3, pp.473-500.

Kose, A, E. Prasad, and M. Terrones Silva, 2003, "Financial Integration and Macroeconomic Volatility," IMF Working Paper 03/50 (Washington: International Monetary Fund).

Kupiec, Paul, 2001, "Is the Ncw Basel Accord Incentive Compatible?" paper presented at a Bank for International Settlements conference in Basel, Switzerland. 
Morris, JoAnne, 2001, "Risk Diversification in the Credit Portfolio: An Overview of Country Practices," IMF Working Paper 01/200 (Washington: International Monetary Fund).

Slack, G., 2003, “Availability of Financial Soundness Indicators," IMF Working Paper 03/58 (Washington: International Monetary Fund).

Wilson, B.M., and G. Caprio, 2002, "Eggs in Too Few Baskets: The Impact of Loan Concentration on Bank Sector Systemic Risk" in "Financial Sector Policy for Developing Countries - A Reader, ed. by Gerard Caprio, Patrick Honohan, and Dimitri Vittas (Washington, D.C: World Bank 2002). 